\title{
Trust, Repute, and the Role of Nonprofit Enterprise
}

[The book version]

by

\author{
Andreas Ortmann* \& Mark Schlesinger**
}

\begin{abstract}
In this chapter we examine the trust hypothesis: the proposition that information asymmetries between providers and consumers of services can explain the existence of nonprofit enterprise in certain markets. We argue that this hypothesis, in order to be viable, has to meet three challenges: (1) the de jure inability of nonprofits to distribute profits to shareholders and/or management must affect incentives within the nonprofit firm in ways that are compatible with trustworthiness (Aincentive compatibility challenge $\mathrm{d}$ ), (2) nonprofit behavior must not be adulterated by individuals taking advantage of the perceived trustworthiness (Aadulteration challenge@), and (3) nonprofit status must be treated as a reliable predictor of organizational behavior by consumers, when the reputation of individual firms is not seen as reliable (Areputational ubiquity challenge@). We propose that the trust hypothesis stands on shaky ground. It can be sustained only under particular conditions that have been neither carefully described in theory nor subject to empirical assessment. The available evidence, patchy and inadequate as it is, seems to suggest that there are ownership-related differences in the organizational behavior of non-profits and for-profits. However, there is little evidence that these differences can be connected to trust per se or provide a rationale for the existence of nonprofit ownership.

* Center of Economic Research and Graduate Education at Charles University and Economics Institute of the Academy of Sciences of the Czech Republic.

E-mail: andreas.ortmann@cerge-ei.cz or aortmann@yahoo.com

** School of Medicine, Yale University.

E-mail: mjs4@email.med.yale.edu
\end{abstract}

Note: A shorter version of this paper has been published under the same title in Voluntas, 8:2, 1997, 97 - 119. The current version has been updated and significantly revised; it is scheduled to appear in a volume edited by Helmut K. Anheier and Avner Ben-Ner tentatively titled The Study of Nonprofit Enterprise: Theories and Approaches, Kluwer/Plenum, 2002. 


\section{A. Introduction}

In this chapter we examine what we label the "trust hypothesis": the proposition that information asymmetries in the markets for certain goods and services can explain the existence of nonprofit enterprise in those markets (Hansmann 1980, 1994, 1996; but see also 2001). Assuming that profit maximizing producers might not have an incentive to deliver the quality of goods and services they promised consumers and/or donors, Hansmann was one the first to claim that nonprofits solve the temptation to exploit information asymmetries by accepting the nondistribution constraint ${ }^{1}$ - the de jure inability of nonprofits to distribute profits to shareholders and/or management. ${ }^{2}$ The nondistribution constraint, Hansmann argued, would effectively take care of producers' incentive to engage in opportunistic behavior. ${ }^{3}$

1 The claim was the elaboration of an observation made by Kenneth Arrow (1963) in his assessment of the welfare economics of medical care.

${ }^{2}$ This defining characteristic suggests the term "not-for-profit enterprise". We follow in this chapter the established but misleading convention of calling not-for-profit firms "nonprofits".

3 Fairnesss requires for us to emphasize that Hansmann formulated his theory in the late 1970s (see Hall et al. 1999) when commercial nonprofits were the exception rather than the rule (Hammack 2001), nonprofits were relatively less important (Hammack 2001), and information not as readily available as it is today. It is no coincidence that economic theorizing throughout the seventies -- arguably prompted by Akerlof (1970) B was concerned with information asymmetries. 
Hansmann's proposition has been a major theme of economic theories of nonprofits and the dominant rationale (Steinberg \& Gray 1993; Oster 1995; Young \& Steinberg 1995; Brody 1996; Ortmann 1996; Glaeser \& Shleifer 2001; see also the various contributions to the present volume). Our goal here is to assess the conceptual and empirical underpinnings of this proposition. In doing so, we focus on what Hansmann refers to as "commercial nonprofits " -nonprofits that generate most of their revenue from the sales of goods and services, though most of the analysis generalizes to donative nonprofits. ${ }^{4}$ Classic examples of commercial nonprofits are health, educational, and day care institutions, as well as nursing homes. These four human services segments will be the focus of our review of the empirical evidence. ${ }^{5}$ We note that all four Aindustries $@$ B including education B are now populated by both nonprofits and for-profits, making the identification of the raison $\mathrm{d}=$ =etre of the nonprofit enterprise an ever more important issue.

We argue that the link between information asymmetries and nonprofit enterprise is subject to three challenges, which we refer to as: (1) the incentive compatibility challenge, (2) the adulteration challenge, and (3) the reputational ubiquity challenge. The first challenge reflects the opportunities for those working in nonprofit settings to pursue various goals whose common denominator is that they are not aligned with the mission of the nonprofit enterprise. The second challenge reflects the temptation for individuals to exploit the trustworthiness that the nonprofit enterprise as such might have. The first and second challenge roughly map into the moral hazard and adverse selection arguments well established in the more recent Industrial Organization literature. The second challenge can be understood as a special case of the first in that the problem of adulteration should be of no concern in equilibrium if the incentive compatibility challenge is met. The third challenge reflects the necessity that, for Hansmann=s proposition to hold, consumers do indeed take ownership as a reliable predictor of trustworthiness in those cases where they do not know whether an individual firm can be trusted. Nonprofits, in short, need to be trustworthy and they need to be trusted. Specifically, for Hansmann=s proposition to hold, nonprofits need to be more trustworthy than for-profits and nonprofits need to be trusted more than for-profits.

Ownership-related differences in trustworthiness and trust are sustainable in competitive

4 Hansmann $(1980,872)$ argued that "the distinction ... between commercial and donative nonprofits is simply one of degree, rather than a difference in kind." To the extent that one can conceptualize "donors" as a special case of "consumers" of the services of a nonprofit, this strikes us as a sensible statement. Empirical evidence supporting this claim has been provided by Galaskiewicz \& Bielefeld (1998, see especially pp. 236 - 237) who find, "in some respects ... meaningful differences" between commercial and donative nonprofits in their panel data but also "many similarities". Indeed, excluding religious nonprofits, most nonprofits rely on a surprisingly small fraction of donations (about 10\% in 1996, down from 16\% in 1980), with the remainder coming from commercial activities (54\%, up from 36\%) and government support (36\%, down from 48\%). In addition, certain donations -- such as donations of alumni to their alma mater -- may be best conceptualized as deferred payments.

${ }^{5}$ This leaves out of the analysis a number of other important segments of the nonprofit and voluntary sector such as social welfare organizations, private foundations, and religious organizations (all of which are exempt from taxes under section 501(c)(3) of the IRS code), as well as the numerous and diverse mutual benefit organizations which are exempt under section 501(c)(4). 
equilibrium only if conditions are such that these three challenges are met simultaneously. We attempt to identify the circumstances under which one would expect this to be true. These are "special cases" in the sense that they require a number of additional assumptions beyond the existence of asymmetric information. Their importance, and thus their potential applicability to industries with substantial nonprofit ownership, is an empirical question. Unfortunately, it is a question that cannot be answered in a very complete manner based on existing research, since very little of this research has been sensitive to the factors identified in this chapter as necessary tests of the trust hypothesis.

The chapter is organized as follows: In section B we sketch the trust hypothesis in historical context and give two examples of trustworthiness and trust -- one an external principalagent problem, the other an internal one. Section $\mathrm{C}$ explores in more detail the conceptual questions posed by the challenges identified in this introduction. Section D discusses special cases under which trust-related equilibria may explain the persistence of nonprofit ownership. Section $E$ reviews the empirical evidence and its limitations. Section F concludes.

\section{B. The Trust Hypothesis: A Brief History and Two Examples}

As mentioned, Hansmann's central proposition was that the non-distribution constraint (NDC from here on) reduced the incentives for those working in nonprofits to claim any financial surplus, and hence reduced incentives to misrepresent their activities to consumers or potential donors (Hansmann 1980: 844, 862, 896; 1994: 2 - 5, $10-12,18,22$ ). ${ }^{6}$ In this sense, nonprofit organizations were taken to be more "trustworthy". In the limit, the NDC offered the comforting promise of exorcizing opportunistic behavior of working in nonprofits completely, rendering nonprofit organizations fully trustworthy. This proposition was subsequently developed with greater mathematical rigor by Easley and O'Hara $(1983,1986)$, Ben-Ner (1986), Chillemmi \& Gui (1991), Hirth (1999), and Glaeser \& Shleifer $(2001)^{7}$, among others. Each of these elaborations focused on particular aspects of the processes that were thought to produce greater trustworthiness.

However, as a number of scholars have observed, neither the original formulation nor its subsequent formalizations created a complete and internally consistent explanation for the role of nonprofit organizations in industries with mixtures of nonprofit and for-profit ownership (Anheier 1995; Steinberg \& Gray 1993; James 1986; Oster 1986). In addition, original formulation and subsequent formalizations were moot on the issue of industries such as computing or air transportation that produce goods whose quality consumers are unable to evaluate in advance. Yet, in those industries trust goods and services are not produced by nonprofits. And never were.

\footnotetext{
${ }^{6}$ Another important rationale was proposed by Weisbrod (1975): Since the government satisfies the demand of the median voter only, nonprofits step in to satisfy the demand for public goods which is not met by the government.

${ }^{7}$ Glaeser \& Shleifer (2001) is a recent prominent entry in the nonprofit theory sweepstakes. They model the incentive compatibility problem of principal agent interaction as one of contractual incompleteness, i.e. rather than relying on consumer ignorance (asymmetric information), they rely on the ability of consumers to verify (the lack of) quality in court. This twist on Hansmann's central claim does not change the basic rationale of his story.
} 
Despite these objections, the use of asymmetric information has become the dominant explanation for the existence of nonprofit organizations (e.g., Oster 1995; Young \& Steinberg 1995; see also Steinberg \& Gray 1993 for a quantitative assessment of the dominant role of the rationale proposed by Hansmann). Hansmann $(1994,2)$ went so far as to state that Ait is general scholarly consensus that ... the nonprofit form serves as a crude but effective consumer protection device in severe situations of asymmetric information. More particularly, nonprofit constraints reduce opportunism where consumers ... are unable to evaluate accurately the quantity or quality of the service that the firm produces for them. The advantage of a nonprofit firm in such situations is that, by virtue of the nondistribution constraint, the managers of the firm are limited in their ability to benefit personally from providing consumers with fewer or lowerquality services than promised, and thus have less incentive to do so."

To fix our use of the words trust and trustworthiness in the present context, and to motivate our discussion of the trust hypothesis, we first discuss two examples:

Example One: A parent wants to purchase day care for her child at a high-quality center. Many of the most important aspects of quality (the skills and experience of staff, the consistency of developmentally appropriate interactions between staff and children) are hard to assess from an initial visit. The parent could reassure herself by making unannounced visits to the center, but this is costly, not entirely reliable, and maybe disruptive. The costs and the attendant worries are eliminated if the parent can simply trust the center to provide the care it has promised, i.e. if the center is trustworthy.

Example Two: The board of directors of a nonprofit organization wants to hire a new administrator. The administrator can actively pursue the organization's goals or, ignoring her initial promises, shirk on her efforts (endangering the reputation of both the organization and its board (Handy 1996).) The board can actively monitor the administrator's performance, but this is costly in time and resources that could be saved if the board can simply trust the administrator to honor her promises, i.e. if the administrator is trustworthy.

Note the parallels: While the first example deals with the external agency problem of consumer-nonprofit interaction and the second with the internal agency problem of boardadministrator interaction, both examples feature an agent (the center, the administrator) who can adjust quality or effort downward and might have the incentive to do so. Both examples also feature a principal (the consumer, the board) who faces the dilemma of trusting the agent's promises, or monitoring her/his performance. Both agent and principal can either contribute their respective assets (honesty for the agent, trust for the principal) or withhold them.

Such situations of strategic uncertainty, or principal-agent interactions, can be usefully couched in game-theoretic form (Kreps 1990; Ortmann 1996). Doing so, it is easy to see the isomorphic incentive problem that consumers, donors, or boards face. Couching principal-agent interactions in terms of game theory, also enables us to draw on its well-established insights regarding the impact of information flows and the comparative advantages of third-party (regulation) and reputational enforcement (which obviously relies on strong information flows) insights which have advanced our understanding of the internal dynamics, and strategic interaction, of firms (Holmstroem \& Tirole 1989).

For a wide range of parameterizations the game-theoretic predictions for principal-agent games, when repeated only once, are indeed rather dismal (and in this respect support the 
Hansmann rationale): Agents will cheat on quality and shirk on effort. ${ }^{8}$ Principals will hence not be able to trust agents and will be forced to engage in costly monitoring activities or not engage in interactions with agents in the first place. The likely outcomes are thus sub-optimal. Importantly, and somewhat simplifying, this result extends to repeated games under weak information flows. Equally, and again somewhat simplifying, this result does not extend to repeated games under reasonably strong information flows where reputation has the potential to constrain opportunistic behavior.

8 See Ortmann \& Colander (1997) for two parameterizations: for one defection is the (weakly) dominant strategy, for the other defection is in the support of the mixed-strategy equilibrium. 
Hansmann postulated that the problem of trust illustrated in our Example Two is of no practical importance for nonprofits because of the NDC, and that therefore the problem of trust inherent in Example One are of no practical importance either ${ }^{9}$. In essence, Hansmann treated the external and internal agency problems asymmetrically when their incentive structure, as suggested by examples One and Two, and their game-theoretic framing is the same. Whether such an asymmetric treatment of external and internal agency problems, and in what direction such as asymmetric treatment, is justified, prompts both interesting conceptual and empirical questions.

\section{The Three Challenges to the Trust Hypothesis}

We discuss conceptual questions in the following two sections and discuss empirical evidence in section $E$.

\section{The "Incentive Compatibility challengee}

Let us assume for now that there are no differences in the preferences of individuals for affiliation with nonprofit and for-profit firms. Let us also assume for now that those founding, and working in, nonprofits are self-interested and not motivated by wanting to do good. Under these conditions, the trust hypothesis postulates that the NDC suffices to effectively constrain the opportunism of founders, boards, managers, and employees of nonprofits.

${ }^{9}$ Fairness requires to note that Hansmann observed that, while the NDC is "more or less clearly embodied in the nonprofit corporation of nearly all the states, most states in fact make little or nor effort to enforce this prohibition." (Hansmann1980: 873) Hansmann (1980), furthermore, observed that the incentives for managerial efficiency may be reduced in nonprofits. He did not see his basic argument -- the trust hypothesis -- crucially affected by this, however. For a recent restatement of his position, see Hansmann (1996). See also Hall et al. (1999) discussing Hansmann (1996) and Hansmann (2000) responding. Last but not least, see Hansmann (2001). 
In doing so, proponents of the trust hypothesis implicitly suggest that the opportunities and incentives for various forms of opportunistic behavior on the part of agents (boards as regards donors, managers as regards boards, employees as regards managers) are negligible and that opportunities for misappropriation will be effectively constrained by the nondistribution constraint. Boards members, managers and their employees, however, often do have interests that are not well aligned with those of the organization or those that fund or founded them (e.g., Oster 1986; James 1986; Rose-Ackerman 1986; Kreps 1990; Ben-Ner 1994; Ben-Ner \& Van Hoomissen 1993; Handy 1996; Ortmann \& Squire 2000) ${ }^{10}$, and profits B while they can not be distributed in an outright manner to nonprofit boards, managers and/or employees -- can be spent on power, prestige, and other perks (Oster 1986; James 1986), influence costs (Milgrom \& Roberts 1990), cross-subsidization (James 1986), and organizational slack (Williamson 1970; Massy \& Zemsky 1994; Ortmann \& Squire 2000).

The common denominator of all these strategies is that resources meant for a particular purpose (such as the various benefits enumerated in section 501(c)(3) that give public charities their lease on life ${ }^{11}$ ) get misappropriated for other purposes, typically self-serving ones. While all of these strategies can also be encountered in for-profits, several factors make them more problematic in nonprofit settings. Historically, nonprofit service providers have been subject to less regulatory oversight than have for-profit organizations providing the same services (Facchina, Showell, \& Stone, 1993). In addition, some critics have argued that many nonprofits have characteristics such as trust, cash donations, and insufficient internal control systems which make them more likely candidates for misappropriation than (other) businesses (Douglas \& Mills 2000; Moulton \& Wilson 2000). Although we do not necessarily agree with these claims, they certainly merit empirical testing.

Opportunistic behavior, of course, is difficult to identify. And can run the gamut from outright fraud and abuse to much more subtle forms such as goal displacement. As we will discuss in the empirical section, it is everyone=s guess what exactly the scope of the problem is. Three reasons seem to be responsible for this deplorable state of affairs: First, state and federal regulators $=$ and the $I R S=s$ limited resources ${ }^{12}$ handicap them in their attempts to enforce the NDC and its sidekick, the reasonable compensation constraint, or to ferret out the ways in which misappropriation can occur (Carr 2000; Gaul \& Borowski 1993). Second, it is not easy to

${ }^{10}$ Since the attempts to re-direct the study of nonprofit organizations by authors such as Rose-Ackerman, Oster, and James, "unpacking the black box" called organization, (i.e., understanding the incentive problems that boards, managers, and workers face) has arguably become the most important accomplishment of modern theories of the firm (Aron 1990; Holmstroem \& Tirole 1989; Abrahamson \& Park 1994; Hart 1995; Hart 2001; see also the references in these papers). Unpacking the black box called nonprofit enterprise seems of paramount importance. Little progress, though, has been made on this front although, as we shall when reviewing the empirical evidence, a better understanding of these issues is highly desirable.

${ }^{11}$ This section requires that an organization, in order to warrant exempt status, is organized and operated for religious, charitable, scientific, educational, and various other purposes that serve a public rather than a private interest.

12 The Charities Bureau of the New York Attorney General's office monitors, with a grand total of six accountants who essentially still operate with 3 - by 5 cards, more than 30,000 charities. 
determine what constitutes an unreasonable compensation, or other forms of misappropriation. Are the benefit packages that some colleges pay their presidents unreasonably excessive (Nicklin 2000)? Are those shares that managers of nonprofits own in their for-profit subsidiaries justifiable (e.g., Labaton 2002)? And how about those generous honoraria for Aresearch reports $@$ that don=t quite deserve the name that the PricewaterhouseCoopers Endowment for the Business of Government pays some academics (Thayer 2002)?

Last but not least, what constitutes abuse or fraud is a social construct that shifts its meaning over time. Some (e.g., Ben-Ner \& Hoomissen 1993; Ben-Ner 1994) have argued (and we agree) that goal displacement B i.e. Athe operation of a nonprofit organization according to the wishes of its executives, or its self-perpetuating board of trustees or directors, or both, while disregarding the wishes of most its beneficiaries, donors, volunteers, and other supporters @ (Ben-Ner 1996) B is a more prevalent form of fraud and abuse than self-dealing or other forms of misappropriation.

So far we have taken as given that those working for nonprofits are not different from those working for for-profits. Young $(1986,161)$, however, noted that Hansmann's rationale for non-profits and similar attempts following his lead have "a self-less, public-spirited quality to them." Implicit is the assumption, which has long become textbook folklore (Young \& Steinberg 1995, 34/5; Oster 1995, 7; see also Ben-Ner \& Gui 1993, 1, or Rose-Ackerman 1996), that those working for non-profits have more altruistic motivations, and in any case are united by their belief in some common good. Jeavons (1994) goes so far as to argue that "trust is the essential lifeblood of the nonprofit sector" (186) and, "the undergirding values of the nonprofit sector are altruistic, ... it is never acceptable for managers to advance themselves at the expense of the people and causes they have promised to serve." (199) Alternatively, it has been argued (prominently by Rose-Ackerman 1996) that ideology is a major driver of those who found, and work in, nonprofits. Specifically, it has been argued that ideological entrepreneurs can overcome the inefficient incentives created by the lack of owners (Rose-Ackerman 1997, 125). Ultimately, both behavioral assumptions -- altruism and ideology -- are an empirical question. ${ }^{13}$

\section{The "Adulteration challenged}

An important complication of the preceding analysis is the undisputable fact that nonprofits -- like for-profits -- go through typical life cycles (Silk 1994; Galaskiewicz \& Bielefeld 1998). If the NDC does not generate incentives within a firm in ways that are compatible with trustworthiness, and altruistic or ideological motivations are the only safeguard against the incentive compatibility challenge, then non-profits -- even if they are often founded by people with altruistic or ideological motivations -- may be susceptible to converting, or being converted into nonprofits that do not deserve their name (Afor-profits in disguise@ as Weisbrod 1988 calls

${ }^{13}$ Unfortunately, it's also a notoriously controversial research area because -- in the kind of principal agent games that we discussed above - veritable altruism is often observationally equivalent to self-interest in game contexts that are repeated indefinitely. 
them). The conversion may be a simple drift resulting from ossification and bureaucratization (and professional nonprofit managers replacing the initial founders) or it may be engineered by managers who have less altruistic or ideologic motivations than the founders. It could also be that pseudo-altruists might try to enter the sector to try exploit the tax and other advantages proffered by nonprofits and, at the same time, the trustworthiness that nonprofits might have earned.

Ironically, the more commonly consumers take ownership form as a signal of organizational trustworthiness (and thus are willing to pay for aspects of service quality that are difficult to verify) the more incentives less ethical providers would have to either take control of an existing nonprofit organization or form a new nonprofit. Ultimately, this suggests that the greater the initial trust, the more likely it is that the trust will be eroded by subsequent violations of trust.

The literature has long identified examples where adulteration has occurred (Etzioni \& Doty, 1976; Goldberg 1975), particularly in industries in which government regulation has restricted entry by for-profit providers. The challenge for proponents of the trust hypothesis is to demonstrate that adulteration of this kind is not extensive in practice or is mitigated by institutional arrangements.

\section{The "Reputational Ubiquity challenge@}

Heal (1976) and Klein \& Leffler (1981) were the first to demonstrate that repeat encounters and reasonably strong information flows could overcome the dire predictions prevalent in the literature at that time. (These authors were concerned with for-profit organizations and their incentives to provide high quality, and not the internal organization of firms.) Specifically, they argued that the outcomes of a game, such as the one represented by our examples One and Two, was likely to be different if the game were to be repeated indefinitely. Repetition combined with reasonably strong information flows makes people care about their track records and the consequences of uncooperative behavior. Specifically, Klein \& Leffler demonstrated that under well-defined conditions, reputation can be more powerful an enforcement mechanism of contractual compliance than third party enforcement. Klein \& Leffler also established that reputational enforcement is particularly effective in situations where intangible characteristics are involved - a situation typical for most experience goods including services such as education and health care, but perhaps not for day care services or long-term care.

Klein \& Leffler's notion of reputational enforcement was later formalized in rudimentary game-theoretic form by exploring the consequences of principal-agent games like examples One and Two above under various conditions (one-shot game versus repeated interaction, strong versus weak information flows). Subsequently the analysis was extended in myriad ways to the internal organization of firms (Holmstroem \& Tirole 1989; Tirole 1988; Kreps 1990). To paraphrase Holmstroem \& Tirole=s succinct dictum, reputation was conceptualized as the soul of organizations. Indeed, the importance of reputation is at the heart of modern Industrial Organization's understanding of the nature of product and factor markets (Stiglitz 1989; Tirole 1988), as well as the internal organization of firms. Reputation has also become, under the label customer satisfaction, the mantra of many for-profit firms even in such areas as computing or air transportation, and as we will see presently, in sectors dominated by nonprofits such as health care and education. Reputational ubiquity indeed. 
Reputation does not work well if interaction is not repeated and information flows are weak. It has been argued that reputation hence does not work well in situations where goods and services are idiosyncratic B a situation more likely when goods and services are produced by labor rather than capital (and thus typical for human services prevalent in the nonprofit sector). The challenge for proponents of the trust hypothesis is to demonstrate that reputation fails as enforcement mechanism for for-profits (such as computer makers or airlines, or for that matter for-profit hospitals and schools), while at the same time consumers and donors treat it as a reliable predictor of organizational behavior of nonprofits (such as non-profit hospitals and schools) by consumers and donors.

\section{Special Cases Under Which Trust-Related Equilibria May Explain the Persistence of Nonprofit Ownership.}

Unless the three "challenges" are met simultaneously, there is no reason to expect nonprofit organizations to be any less opportunistic than their for-profit counterparts. Nonprofit organizations will be more trustworthy and more trusted only under some special circumstances which we explore next. ${ }^{14}$

1. The Reputational Ubiquity challenge: We have argued that the need to maintain a positive reputation will generally discipline the practices of nonprofit and for-profit firms alike. When the actions of misrepresenting firms will become known, their claims will be discounted, and hence the advantages of exploiting information asymmetries will be eventually eliminated. Reputation, however, does not work well if interactions are not repeated or information flows are weak. In what follows we sketch out the conditions under which the trust hypothesis might work.

Reputation might not work well in markets in which there is considerable technological change. Reputation takes time to build, and may thus not be a good guide to predict organizational performance in environments where information flows are weak and purchases infrequent. To the extent that trustworthiness matters particularly in these circumstances, and to the extent that nonprofits initially may be less afflicted by incentive problems (due, let=s say, to founders with altruistic and/or ideologic motivations), one would therefore expect an ownershiprelated life-cycle to exist in industries, with nonprofit organizations disproportionately found in the early stages of the development.

It has also been argued that reputation might not work well in situations where goods and services are idiosyncratic -- a situation more likely when they are produced by labor rather than capital (and thus typical for human services prevalent in the nonprofit and voluntary sector.) Longterm care or psychiatric care may be good examples. In these human services segments,

14 In referring to these as "special circumstances", we mean to imply nothing about their prevalence in the economy as a whole or in particular markets, only to point out that they represent conditions that go beyond those stated by Hansmann or the subsequent efforts to formalize his work. 
information flows depend in addition on the willingness of people to share their experiences. That willingness may be lower in long-term care environments where the service recipient, as Hirth $(1999,222)$ points out, Ais often neither the decision maker nor able to easily evaluate care. A That willingness may also be lower in psychiatric care because of its social stigma. See Weisbrod (1988) for a discussion of services of this type.

In sum, one would expect the shortcomings of reputation to be most pronounced in newly emerging industries and reputational safeguards to be least effective for services with idiosyncratic quality. Over time, reputational effects become more important, so that the betterinformed clients become indifferent between nonprofit and for-profit settings and the nonprofit providers become disproportionately patronized by those who feel themselves to be most at risk of misrepresentation (Hansmann 1987; Hirth, 1999). This, curiously, creates a situation in which for-profit providers will appear quite trustworthy, since they largely serve a clientele that is relatively well-informed. Consequently, one would expect to observe in empirical research that nonprofit providers were more trusted, but not any more trustworthy in their behavior. ${ }^{15}$

2. The Incentive Compatibility challenge: While the NDC is not inherently antithetical to misrepresentation, one would expect to find more trustworthy behavior in nonprofit settings under the following conditions. Trustworthiness may itself be a form of nonpecuniary compensation. In other words, apart from the market consequences of reputation, those affiliated with an organization may take special pride in being part of a trustworthy enterprise. If indeed the NDC causes a shift from pecuniary to such nonpecuniary rewards, one would expect this pride in reputation to play a larger role in nonprofit settings than in otherwise comparable for-profit firms.

Trustworthiness may also be created indirectly by the pursuit of other nonpecuniary goals in nonprofit settings. It has been argued, for example, that nonprofit service providers will favor higher levels of quality than those found in for-profit settings, because high quality generates prestige as a form of nonpecuniary reward (Newhouse 1970). Assume that this is correct and nonprofits would provide a higher level of quality even to fully informed consumers. What does this imply for the potential for misrepresentation? Assuming the quality has a declining marginal utility for consumers, the potential benefits (in terms of increased revenues) for a nonprofit firm

${ }^{15}$ If one focused only on relatively uninformed consumers, however, one would expect to find ownership-related differences in trustworthiness. Whether differences in trustworthiness and trust would be sustained over time depend on the ways in which services are delivered.

Because nonprofits behave in a trustworthy manner, there is no reason for uninformed clients to revise their expectations. If uninformed clients ventured to patronize a for-profit provider, they would be treated in a less trustworthy manner as long as the provider can treat its informed and uninformed clients differently. If, however, its services are standardized, then the desire by forprofit providers to not damage their reputation among informed clients will protect the quality for uninformed patrons. 
pretending that it has higher quality than it actually delivers would be less than for a corresponding for-profit firm. Consequently, simply as a result of self-interested behavior, one would expect to find less misrepresentation in nonprofit firms.

3. The Adulteration challenge: Ownership related differences in trustworthiness are not necessarily associated with differences in trust. Where consumers are unaware of ownershiprelated differences in misrepresentation, there are no incentives for adulteration, because consumers are not rewarding nonprofits for their reduced willingness to exploit informational asymmetries. However, to the extent that nonprofit organizations are more trusted than are their for-profit competitors, it allows them to charge more for a given level of promised quality. ${ }^{16}$ These higher prices create an incentive for less reputable entrepreneurs to enter the market as nonprofit organizations and use these higher returns to surreptitiously increase their incomes (for-profits in disguise).

Several other factors, however, may buffer the nonprofit sector against adulteration. As suggested above, nonprofit organizations are disproportionately represented among the pioneers in new health and human services. To the extent that the firms consumers see as more trustworthy are both nonprofit and long-established, it makes it impossible for newly entering nonprofit firms to capture the same advantages in terms of consumer expectations. A substantial number of nonprofit organizations operate with affiliations to churches or other religious organizations (Weisbrod 1988). To the extent that consumers trust only religiously affiliated nonprofits, it may be difficult for disreputable entrepreneurs to create similar sorts of affiliations. ${ }^{17}$ Religious affiliations may provide some protection from internal adulteration, because they connect the organization to another group that can monitor its performance over time.

A second buffering factor may involve the extent of professionalization among service providers. Sociologists have observed that professional norms play an important role in the behavior of nonprofit organizations (DiMaggio \& Anheier, 1990). Professional norms create powerful incentives that limit the extent to which the behavior of individual providers deviate from those for the sector as a whole (DiMaggio \& Powell, 1983). These norms, however, are likely to be more effective in industries where professionalism is more pronounced (e.g. hospitals) than those where professionals play a less central role (e.g. nursing homes and day care).

\section{E. Review of Empirical Work}

${ }^{16}$ Price differences of this sort should be generated in a variety of ways. Consumers will be willing to pay for the expected quality they think they will receive, whatever the promised quality from the provider organization. For more trusted firms, expected quality should be closer to promised quality than in less trusted venues. Alternatively, consumers may need to spend resources monitoring quality themselves. For example, parents concerned about the quality of day care being provided to their child will likely take the time to drop in and periodically observe the day care center (Mauser, 1993; Nelson and Krashinsky, 1973). Monitoring of this sort has opportunity costs. Parents who trusted the center enough that they did not have to spend their time observing its practices would be willing to pay more to avoid these time costs.

${ }^{17}$ There will, of course, always be the religious charlatans who establish their own churches for purposes of self-enrichment. 


\section{Preliminary remarks.}

Before reviewing the empirical work, it is useful to make several observations about the relationship between theory and empirical findings. None of the research cited below purports to establish that differences in trust and trustworthiness are the central rationale for nonprofit ownership in a given industry. As noted earlier and also in the other chapters in this book, there are a variety of other explanations for the existence of the nonprofit sector. No study that we know of has attempted to demonstrate that trust can sustain a nonprofit sector, in the absence of these other factors. Indeed, to the best of our knowledge no empirical work has even juxtaposed the trust hypothesis against a single one of these competing explanations (e.g., Weisbrod=s public good argument) ${ }^{18}$.

Better understanding the interaction of the different factors that affect nonprofit ownership is particularly important for clearly assessing the role of trust. Evidence consistent with trust may be the inadvertent byproduct of other ownership-related differences. Assume, for example, that one observes individuals with more limited education disproportionately patronizing nonprofit firms. This is consistent with the trust hypothesis since such individuals will find it more difficult to collect and assess information in order to guard against misrepresentation. But this evidence is also consistent with nonprofit firms subsidizing services to low-income consumers (who will, on average, be less educated as well) as a form of public good.

Trust, in contrast, may be the source of nonprofit ownership, even if it is not sustainable in equilibrium. We noted earlier that the reputational safeguards are likely to be least effective in newly emerging industries, and/or when the quality of goods and services is idiosyncratic. Under these circumstances, differences in trust and trustworthiness may allow nonprofit organizations to introduce new services that would otherwise be viewed skeptically by consumers. Even if this initial trust is adulterated by the subsequent entry of less ethical providers, once nonprofit firms are established in a market, they may continue to exist because of other ownership-related differences, such as different set of stakeholders, different clients, or the numerous privileges and exemptions enjoyed by nonprofit organizations. Consequently empirical studies that measure trust or trustworthiness in mature markets may find no ownership-related differences, even though trust was primarily responsible for the introduction of nonprofit ownership to the market.

Because characteristics such as technological change, reputational effects and the role of religious affiliations vary from one industry to the next, one would also expect to find measurable differences in the extent of ownership-related patterns in trust or trustworthiness. For example, one would expect to see trust differences to be more important for day care, where many providers are small and unaffiliated, than for higher education, where most of the services are provided through large institutions with well-established reputations. In health care, one would expect general hospitals to display fewer differences in trustworthiness because of their prominent position in their communities (and hence strong reputational effects). One might, however, expect there to be significant ownership-related differences for nursing homes or psychiatric hospitals, where the stigma of using the facility discourages people from discussing their experiences (or those of their family members) and hence limits reputation effects. The

${ }^{18}$ Leete $(2001,159$ - 160) tests Preston's (1989) conjecture that workers engaged in public good production donate more labor. She finds that the evidence is "not entirely consistent" with the conjecture. 
central point is that one should expect to find differences in patterns of trustworthiness across industries and that some industries are predictably more likely candidates than others having trust matter in the distribution of ownership.

\section{The Existing Evidence}

Much of the past empirical research relevant to the trust hypothesis has been examined previously (Rose-Ackerman 1996; Steinberg \& Gray 1993). Our main purpose here is to incorporate more recent empirical research and to explore its implications. We then consider ways in which future empirical research might be directed to help us better understand the relationship between ownership and information asymmetries.

Empirical literature relevant to the trust hypothesis can be placed into 4 distinct categories: (1) Is opportunistic behavior effectively constrained by the nondistribution constraint? (2) Are those founding, and working in, nonprofits more altruistic and/or ideological than those associated with for-profits? (This second question can be addressed either by direct studies of motivation or through the indirect evidence of compensating wage differentials) (3) Are there ownership related differences in quality in services, in those dimensions which are harder for consumers to observe? The fourth, and final, category addresses the reputational ubiquity challenge: (4) Are consumers aware of differences in ownership among the organizations that provide them with services? If so, do consumers expect nonprofit organizations to behave in a more trustworthy manner than their for-profit counterparts. Our discussion focuses on education, health, day care and nursing homes.

Is opportunistic behavior effectively constrained by the nondistribution constraint? As mentioned, opportunistic behavior is difficult to identify and can run the gamut from outright fraud and abuse to more subtle forms such as goal displacement. The more visible range of fraud and abuse was illustrated throughout the nineties by such episodes as the Aramony/United Way, the Bennett/New Era Philanthropy, the Baptist Foundation of Arizona, the Bishop Trust, and Silber/Seragon and Diamandopoulos/Adelphi University scandals. These episodes may have undermined the public=s trust in the nonprofit and voluntary sector (Herzlinger 1996; Odenthal 1990, Gaul \& Borowski 1993, Bennett \& DiLorenzo 1994, Glaser 1994, Lewis, 2000); they certainly reinforced lawmakers $=$ concerns ${ }^{19}$.

Fraud is more readily measurable, but hard (due to its hidden nature) to assess in any systematic manner. Still, there is considerable evidence of fraud among commercial nonprofits. Sparrow (2000), for example, claimed that fraud and abuse bleed annually in excess of hundred

${ }^{19}$ In the wake of the United Way scandal, and as a way to generate more revenue, Congress adapted "the existing private foundation rules on conflicts of interest to charities and 501 (c)(4) advocacy groups. The resulting rules were considered to be between doing nothing and withdrawing tax exemption - hence 'INTERMEDIATE sanctions.' ... The intermediate sanctions rules are 'conflicts of interest' rules on steroids. The power of the IRS is put behind a scheme designed to insure that any financial transactions with insiders are reviewed by persons who have no involvement or interest in the proposed transactions." (Zall 2002; see also Federal Register 1/23/2002). It is too early to assess whether these sanctions will have the bite that they have on paper (penalties include personal excise tax liability of up to $200 \%$ against the benefiting insider and $10 \%$ against the managers who knew of the excess benefits provided to the insider). 
billion dollars from the $\$ 1$ trillion US health care expenditures. We are not claiming that the nonprofit sector is necessarily any more subject to fraud than are for-profit organizations providing comparable services. In the past 7 years alone, the federal government in the United States filed or settled fraud claims against investor-owned health care corporations totaling close to $\$ 3$ billion (Schlesinger \& Gray, 2003). We do claim that there seems little in nonprofit tax status that reduces this threat.

Goal displacement, of course, is even more difficult to identify. The history of conversions of hospitals from nonprofit to for-profit status, and the accompanying attempts to redefine the mission of the converted entities (and the accompanying attempts to usurp charitable assets), may be a good example (Needleman 1997; Cryan \& Gardner 1999). ${ }^{20}$ To the extent that the rapid emergence of a post-secondary education sector that caters particularly to minorities and lower strata of society might reflect a failure of traditional colleges and universities to meet particular social needs, we may have another good example (Ortmann 1997,1998, 2001).

All things considered, there is no clear-cut empirical evidence out there that speaks persuasively to the issue of opportunistic behavior in nonprofits. There is in particular no evidence that conclusively suggests that, in comparison to for-profits, opportunism is higher or lower in nonprofits. ${ }^{21}$ The evidence that is out there and that we have sketched suggests in our view that the NDC is at best, Aa weak guarantee that gifts are not being syphoned off as profits. @ (Rose-Ackerman 1997, 120).

Are those founding, or working in, nonprofits more altruistic and/or ideological than those associated with for-profits? If indeed the NDC is only a weak guarantee that profits are not being diverted to private gain, can we rely on altruistic and/or ideological motivations as safeguards against the incentive compatibility challenge? Again, we know surprisingly little about the motivations of those founding, or working in, nonprofits. Putting aside normative declarations and wishful thinking (e.g., Jeavons 1994), there are several lines of research addressing this question.

${ }^{20}$ As may be the recent Red Cross WTC funds diversion attempts (apparently part of a wellestablished routine of funds diversions, e.g., Sontag 2001).

${ }^{21}$ Assuming that it is about the same clearly does not bode well for the incentive compatibility challenge, and hence, the trust hypothesis. 
The first involves recently emerging methods in experimental economics. Drawing on Ledyard (1995), the contribution rates in multi-person prisoner's dilemma games [public good games] are taken as proof that the predictions of A'hard-nosed' game theorya are dubious (RoseAckerman 1996, 1997, see also Kingma 1997 ). Recent theory developments and methodological discussions, however, suggest that the problem lies not so much with the gametheoretic predictions as with simplistic interpretations of game theory and experimental data (e.g., Goeree \& Holt 1999, 2001), or issues of experimental design (Hertwig \& Ortmann 2001). Our reading of the evidence is much more favorable to game-theoretic predictions which presume a largely self-interested set of motivations for most actors. But even if selfishness does not always carry the day, such a result would not necessarily imply that Aaltruists a would select themselves into the nonprofit sector and selfish people into the for-profit sector. This self-selection, too, is an empirical question. With the laudable exception of the Anatural experimente reported in Duggan (2000), we are not aware of any evidence that would speak to the issue. ${ }^{22}$ It is surprising to note that experimentalists have studied subject pool effects or intercultural differences extensively but somehow have not yet stumbled over this issue.

A second approach that researchers have used to verify the altruism and ideology claims is through wage or compensation differentials. The basic idea behind the approach is the belief that altruistic or ideological motivations ought to translate into differences in compensation (schemes). A recent study by Leete (2001) has shed by far the most comprehensive light on the issue so far. Using observations on 4.1 million private-sector employees from the 1990 census, controlling for a number of important population variables such as gender, education, and working hours per week ${ }^{23}$, and replicating a number of well-known earlier studies of such differentials (e.g., Preston 1989 for economy-wide nonprofit wage differentials; Preston 1988, Borjas, Frech, \& Ginsburg 1983, and Weisbrod 1983 for wage differentials in the day care industry, the nursing home industry, and for lawyers, respectively), Leete $(2001,167 / 8)$ finds that Athere does not appear to be a single economy-wide nonprofit-wage effect ... There do appear to be significant differences between nonprofit and for-profit wages within particular occupations and industries, however.a

Specifically, Leete finds statistically significant nonzero differentials in 34 (of 91) three digit industries. For the 17 industries of those 34 industries that have a nonprofit density of $5 \%$

22 Duggan (2000) studies the differential impact of the Disproportionate Share Program (DSP) through which the California state government tried to increase hospitals financial incentives to treat indigent patients. This nonlinear threshold scheme provided hospitals with significant funds if a certain percentage of its patients was indigent. Duggan finds that nonprofits and for-profit hospitals that were entitled to such DSP payments reacted in essentially the same manner : they "cream-skimmed the most profitable indigent patients from public facilities while continuing to avoid the unprofitable ones." (1345) Both used the DSP revenues "primarily to increase the holdings of financial assets, rather than improve medical care for the poor." (1345) These two results lead Duggan to conclude that the decision makers in nonprofit hospitals are not any more altruistic than those in for-profits.

${ }^{23}$ See her Table 2: Of those working in nonprofits $66.6 \%$ are female, of those working in for profits $43.9 \%$ are female. High school graduates or GED account for $35.2 \%$ of the workforce in for-profits and $21.7 \%$ in nonprofits. $13.5 \%$ and $3.0 \%$ of those working in for-profits have bachelor's degrees or master's degree, while the corresponding numbers for nonprofits are 22.6 and 12.6. Finally, the percentage of part-time workers is about twice as high in nonprofits. 
or more ${ }^{24}$, she finds that about half of the nonprofit/for-profit differentials are positive and about half negative. Leete finds negative differentials (i.e., lower wages in the nonprofit sector) in legal services, broadcasting, publishing, theaters and movies, entertainment, elementary and secondary schools, job training and vocational rehabilitation, and research development and testing. She finds positive differentials in hospitals, nursing and personal care facilities, day-care centers, colleges and universities, and other educational services. She thus finds positive differentials in exactly those areas that we focus on (and that were also the focus of Hansmann 1994). She also finds positive differentials in areas such as electric light and power utilities, telephone companies, urban transit providers, and in the insurance industry.

What do these results tell us about the ability of the NDC, and/or altruistic and ideological motivations, to constrain opportunistic behavior? They clearly suggest that those who work in nonprofit settings do not do so in expectation of sacrificing income for some other nonpecuniary reward, whether altruistic in nature or otherwise motivated. In contrast, the evidence on those who run nonprofit enterprises tends to be rather different. Studies of top level executives typically find that there are compensating income differences, with those working in nonprofit settings earning significantly less than their counterparts in for-profit settings (Roomkin \& Weisbrod 1999, Weisbrod \& Erus 2001). This second set of studies may reflect motivational differences, depending on the roles played by different actors in complex organizations. Or they may reflect the greater ability to control for other worker characteristics in studies limited to particular services or industry ${ }^{25}$ (See, for example, Ballou \& Weisbrod 2002; Morris \& Helburn 2000). ${ }^{26}$

While it is encouraging to note that the well-established dearth of theoretical knowledge about self-selection of consumers and entrepreneurs into sectors (e.g., Steinberg 1993) has prompted interesting attempts to explain nonprofit entrepreneurship (e.g., Bilodeau \& Slivinski 1996 and Bilodeau 1998), it remains a deplorable fact that empirically we do not really know much about the motivations of those that found, or work in, nonprofits. We also know little about the motivations of donors although recent work by Glazer \& Konrad (1996) and Harbaugh (1998, 1998a) suggests that altruism may be less important an explanans than the temptation to buy prestige that flatters the ego.

24 The estimated aggregate employment is estimated to be somewhere in the $8.9 \%$ to $10.9 \%$ range, see Leete $(2001,166$.

${ }^{25}$ In their study of managerial compensation and incentives and for-profit and nonprofit hospitals, Roomkin \& Weisbod (1999) find that total monetary compensation for the two top executive jobs is substantially higher in the for-profit sector and that the composition of compensation between base salary and bonus differs materially across organizational forms, with bonuses being bigger in the for-profit sector. (While a similar study of education providers does not exist yet, the anecdotal evidence from the Chronicle of Higher Education annual salary surveys and $10-\mathrm{K}$ forms points in the same direction.) Ballou \& Weisbrod (2002) find, again for the hospital industry, differences in CEO compensation even among government, secular nonprofits, and religious nonprofits. In contrast, Weisbrod \& Erus (2001) B while refining the results of Ballou \& Weisbord (2002),-- find no differences for middle management or technical workers for these organizational forms. (It is not clear whether these results extend to for-profits.)

${ }^{26}$ Interestingly, "the magnitude of industry-specific nonprofit differentials tends to increase, not decrease, as industries are disaggregated." (Leete 2001, 159) 
The largest gap in the literature on wage and compensation differentials involves the failure to match wages to the performance of particular organizations. For the reasons argued above, ownership-related differences related to trustworthiness are not likely to hold for all nonprofits compared to all for-profit firms in an industry. To the extent that these differences depend on other ancillary characteristics of the firm (religious affiliation, long presence in particular markets), we should observe them for only some nonprofit firms. But if this is true, the notion of a generic nonprofit wage differential makes little sense. One would only expect this differential to emerge for the firms that are actually acting in a more trustworthy or altruistic manner. But no study to date has matched the economic return for workers or executives to these other dimensions of performance in the firms where they work.

\section{Are there ownership-related differences in quality in services?}

Yet another approach researchers interested in altruistic and ideologic motivations have taken is the study of the quality of goods and services that nonprofit workers produce. This approach is motivated by a rationale similar to the compensating differential one and is plagued by methodological problems similar to those afflicting the study of wage and compensation differentials. But there are two additional challenges in addressing this aspect of behavior. First, the tax advantages accorded nonprofit enterprise may facilitate some differences in quality which may have little to do with legal status per se. Second, quality differences that are observed in research may bear little relationship to the trustworthiness of the organization. Trust comes into play only for those dimensions of quality that are not readily observable to potential clients. But the more observable dimensions are also the easiest to study empirically, leading researchers to focus on those dimensions of quality that are actually least relevant for testing claims about trustworthiness.

Comparing variations in the quality of services across organizational forms has become something of a growth industry lately. Many of the recent articles and manuscripts have been able to rely on more comprehensive and geographically diverse data sets and also employed more sophisticated econometric techniques. We provide here an overview of the literature and discuss below some of the key papers related to health, educational, day care and nursing homes.

Health care. Hospitals remain one of the most extensively studied aspects of the medical care system. Over the past 20 years, a large number of studies have compared nonprofit and for-profit facilities in terms of a variety of quality outcomes. A review of this research reveals that the majority of these studies find no significant consistent ownership-related differences in quality of care (Schlesinger \& Gray 2003). More precisely, of the 27 methodologically sophisticated studies that have been published, 20 find no significant quality differences, 6 find differences favoring nonprofit hospitals, and one finds differences favoring for-profit facilities.

This general pattern can be illustrated by two of the more recent studies. In one of the most careful studies yet (measuring program costs and outcomes longitudinally, controlling for numerous health and other patient characteristics, locational decisions of hospitals according to ownership type, and using also various outcome measures), Sloan et al (2001) analyze program cost and quality of care for Medicare patients hospitalized following the onset of four common conditions (hip fracture, stroke, coronary heart disease, and congestive heart failure), during the period 1982 - 1995. The authors analyzed both Medicare payments during the first six months after admission and various outcome measures such as mortality rates and likelihood of continued living in the community and found that-- while providing apparently the same quality of care B for-profit hospitals charged Medicare more than government supported hospitals or their 
non-profit counterparts. While computed payment differentials depend on the regression specification and payment definition, as well as the reference point (government or nonprofit) the reported results suggest that for-profit hospitals charge between $8-16 \%$ more than government supported hospitals and $5-14 \%$ more than their nonprofit hospitals. Given that mean medicare payments for the six months following the health shock were $\$ 13,500$ (1994 dollars), we are not just talking about a dime=s worth of difference. The differences reported for government supported and nonprofit hospitals seem to support the soft budget constraint theory of government-owned institutions proposed by Duggan (2000).

In another careful study, Kessler \& McClellan (2001) find that hospital ownership affects heart attack care (AMI patients). Specifically, they analyzed data on medical expenditures, mortality, and rates of cardiac complications for the vast majority of non-rural elderly Medicare beneficiaries for the 1985 - 1996 period. Their study controls more carefully than earlier studies for selection bias brought about by patient heterogeneity and the cost-reduction spillover effects that the presence of a for-profit seems to trigger. The authors find that Ahigher market density of for-profit hospitals results in significantly lower hospital expenditures for AMI patients, with no consequential effects on their mortality or cardiac health. ( (Kessler \& McClellan 2001, 28) The authors estimate these cost-reducing spillover effects to be 2.4. percent. They also find that most of these gains are captured when the fraction of admissions to for-profit hospitals turns positive. In other words, even a relatively small degree of competition seems to force significant market discipline on other hospitals with other organizational forms.

Education. Assessing the issue of differential quality in this area is difficult because education has gone through a significant transformation over the past decade that seems to follow a similar pattern as the one that transformed the health care industry between the mid-1970's and the mid-1980's. As detailed in Ortmann (1997, 1998, 2001), the number of publicly traded degreegranting providers of higher or postsecondary education in the USA has grown at a steady pace throughout the 1990s. While these companies currently command only about $2 \%$ of the revenues flowing into higher or postsecondary education, indications are that their existence will have salutatory efficiency effects similar to the ones that Kessler \& McClellan (2001) claim for for-profit hospitals. It is noteworthy that for-profit providers of higher or postsecondary education have grown, and continue to grow, at a multiple of the rates with which government-owned or private nonprofit firms grow, and that while initially they competed with community colleges, they have become in their curricular offerings similar to mere traditional colleges and universities (which themselves clearly have taken a page or two from the for-profits' playbook). The extraordinary growth rates of for-profits in this area suggest that these firms, at least in the perception of those that foot the bill (often employers), provide a competitive quality.

Securities analysts following the industry have argued that the rapid grwoth of for-profit degree-granting providers of education in the USA reflects a failure of goverment-owned and private nonprofit colleges and universities to meet demands for particular forms of innovative education (Ortmann 2001). This strikes us as a fair assessment; it is hard to come up with another persuasive story that could rationalize how this new breed of providers of post-secondary education (and their recent e-learning spin-offs and imitators) could successfully compete against traditional providers that do not have to produce profits to please investors and that are favored by numerous regulatory and tax breaks including tax-deductible donations (Facchina et al 1993). ${ }^{27}$

${ }^{27}$ The list that Facchina et al. produce is most impressive: For example, federal income tax 
Whether indeed the higher growth rate of publicly traded degree-granting providers of post-secondary education is a good indication of competitive quality and innovation is too early to tell; time will have to tell. Ortmann $(1998,2001)$ suggests that the major reasons why companies such as the Career Education Corporation, Corinthian Colleges, Education Management Corporation, Strayer Education, De Vry, and the Apollo group/University of Phoenix have been successful has, apart from a very different business model, their focus on retention, graduation, placement, and referral rates, i.e., their understanding of the reputational consequences of giving in to the kind of opportunistic skimping that or-profits have been accused of. The author also suggest that it is exactly this lack of understanding of reputational issues that led to the demise of Computing Learning Centers and contributed to the consolidation of this for-profit segment of the post-secondary education industry.

Day care institutions. A number of studies on day care have addressed both tangible (and therefore easy-to-measure) and intangible (hard-to-measure) aspects of quality of services. Recent studies on day care institutions also had the advantage on being able to draw on large and regionally diversified data such as the Cost, Quality, and Child Outcomes in Child Care Centers set that draws on surveys administered in 400 child care centers in California, Colorado, Connecticut, and North Carolina (e.g., Helburn 1995; Mocan 1995, 1997, Morris \& Helburn 1997). An interesting feature of this particular data set is its detailed measures of easy-to-detect and hard-to-detect measures of quality. The finding a that there is no difference in average quality of the services produced between nonprofit and for-profit centers @ Mocan (1997, 885), has been confirmed although more recent analyses have also suggested that the picture is at a more disaggregated level more complicated than Mocan concluded. ${ }^{28}$ Morris \& Helburn (2000), for example, also find that Athere are no differences in overall quality by profit status except in the state with low licensing standards@ (North Carolina). ${ }^{29}$

Identifying seven different subsectors (for-profit chains, for-profit independents, church operated and affiliated, nonprofit independent, community agency, and public), Moris \& Helburn (2000) find, however, significant quality differences that seem to result at least in part from

exemptions, federal income tax deductions for contributions, income tax-exempt government bonds, income tax-deferred retirement and compensation plans, state income tax exemptions, federal estate tax charitable exemptions, federal tax deduction for taxable inter vivos gifts, unemployment insurance tax exemption, state sales, use, and property tax exemptions, a number of antitrust law exemptions, and special second and third-class nonprofit rates. (This list is not complete.) Facchina et al. do not try to put a price tag on the sum of these privileges and exemptions, and we are not aware of any studies trying to do so. Clearly, we are not talking peanuts here. It is a curious comment on the state of research about the nonprofit and voluntary sector that no published study has yet tried to put a price tag on the sum total of these various tax and regulatory breaks.

28 "This result is important because it demonstrates that on the average, the hypothesis of for-profit centers taking advantage of the information asymmetry on quality is incorrect, and indicates that nonprofit status cannot be taken as a signal of higher quality." (Mocan 1995, 26)

29 The important role of licensing and regulations such as number of mandated inspections had previously been observed by Chipty (1995) who, drawing on data from the 1990 National Child Care Survey found them to be binding. 
market segmentation. For example, the four for-profit and church-related subsectors served mainly unsubsidized children of middle-income working parents. In contrast, nonprofit independent, community agency, and public auspices served larger proportions of low-income children, and Aalmost three quarters of the children served by centers operated by community agencies were publicly subsidized preschoolers from low-income, minority families. @ (Morris \& Helburn 2000, 387).

Indeed, analyzing their disaggregated data Morris \& Helburn (2000) find intriguing differences: centers that are part of a for-profit chain skimped, compared to both for-profit independent (especially in preschool rooms) and nonprofit independent centers (in both preschool and infant/toddler rooms), on hard-to-detect quality. Morris \& Helburn interpret these findings as evidence of the kind of opportunistic skimping that is the basis for Hansmann=s rationale. In fact, they note that for-profit chains seem to work hard to produce higher levels of quality on easy-to-observe characteristics than for-profit independents, suggesting that these chains do not feel constrained much by reputational concerns. Similar results have been reported by Gelles (1999).

These results make sense in light of the industry structure: regulatory oversight of child care centers is minimal, licensing enforcement meager in most states, and parents have limited access to good information; there is no Consumer Reports or US News and World Rankings for child care, only about $5 \%$ of the centers are accredited by the early care and education profession, and most parents apparently do not use the resources and referral agencies that do exist (Morris \& Helburn 2000, 380-1) Reputation flows, in other words, are weaker than may be optimal.

Nursing Homes: Like hospitals, nursing homes have been extensively studies for quality differences related to ownership (Schlesinger and Gray, 2003). But for these services the overall pattern of results is strikingly different. Out of 29 empirical studies that are reasonably sophisticated in their statistical methods, 20 find significant ownership related differences favoring nonprofit facilities. Seven find no significant ownership differences and two find outcomes that favor for-profit ownership.

Again, we can illustrate this broad pattern of results with some recent studies. In the first national ranking of for-profit chains and religious groups operating nursing homes, Consumer Reports, based on inspection reports of the Health Care Financing Administration, finds that "forprofit chains and those with religious affiliations are about equally represented in the top-third of the Ratings." (519); they also find that "individually owned, for profit facilities on average seem to have the poorest records and that the small number of government-owned nursing homes are better than average" (527), and that there is a high degree of heterogeneity within chains. Hirth (1995) found that there are no significant differences in the number of therapies offered at the facility, which can be assessed by prospective purchasers. However, for-profit nursing homes actually provided fewer services to their residents, although there were no significant differences in the level of physical and mental disabilities between residents in for-profit and nonprofit facilities. $^{30}$ Along similar lines, Bradley \& Walker (1998) have studied how organizational form

${ }^{30}$ One might also expect that regulatory violations capture aspects of hard-to-measure quality, since presumably regulations are established precisely because market pressures are insufficient to maintain quality considered to be appropriate from a societal perspective. Here the evidence is more mixed. For both nursing homes (Weisbrod \& Schlesinger, 1987) and psychiatric hospitals (Mark, 1992), for-profit facilities were significantly more likely to have 
affects educational efforts regarding advance care planning. They find that nonprofit and for-profit nursing homes in Connecticut in 1995 are equally likely to discuss the use of life-sustaining medical treatment (a requirement imposed by the Patient Self-Determination Act of 1990 that is easy to observe) although there are significant differences in the way these discussions are implemented (i.e. details that are harder to observe), with nonprofits doing a more comprehensive job in various dimensions (timing, breadth, and support services).

Completing the picture, Luksetich, Edwards, \& Carroll (2000) find similar differences in performance among for-profit, nonprofit, and government-owned nursing homes in Minnesota (although their performance measure is spending on resident care which may, or may not, be a good proxy for quality of care). Specifically, they find that government-owned and nonprofit homes spend more per resident day for nursing care costs than do independent for-profit homes. Chain affiliation is important in explaining persistent spending patterns, with lower nursing cost per patient day and higher general and administrative expenses reflecting possibly agency problems that both nonprofits and for-profits face. This result, like the results by Morris \& Helburn (2000) for daycare centers, suggests that aggregate data tell a very incomplete story and that even in a relatively strict regulatory environment such as Minnesota, significant differences may exist that are driven by other than the traditional tri-partite division of organizational units in government-owned, and private nonprofits and for-profits.

Summary of Findings: Clearly, the above results do not allow for any sweeping conclusions. For one we are dealing with four very different industries, with the hospital industry in the USA currently having $15 \%$ for-profits, $60 \%$ nonprofits, and $25 \%$ government operated. Likewise, (higher or postsecondary) education has an even smaller but rapidly growing for-profit segment, with nonprofits and government-operated colleges and universities dominating the industry. In contrast, roughly $60 \%$ of child care centers are nonprofit (including relatively few publicly operated) and roughly $40 \%$ are for-profits. The numbers are the reverse for nursing homes, with the number of for-profits leading nonprofits by a wide margin.

In health care and education, information flows are clearly stronger (US News and World Report rankings, Consumer Reports, etc.) and we propose that it is for that reason that quality differentials seem less of a problem than in day care and nursing.

Are consumers aware of differences in ownership among the organizations that provide them with services? While clearly prior to the questions we discussed above, this question has received remarkably little attention, given its importance for the trust hypothesis. This evidence suggests that consumers have some awareness of ownership, but that their impressions are not always reliable. In Mauser's (1993) survey of parents with children in day care, 56 percent of the parents were able to correctly identify the form of ownership under which the center operated. Interestingly, only 14 percent of the parents cite the form of ownership as an important determinant in their choice of a program. Almost all of these parents use nonprofit centers.

violated quality standards than were nonprofit facilities. Controlling for other facility characteristics, the ownership-related difference for nursing homes was eliminated, but that for psychiatric hospitals persisted. 
Schlesinger \& Gray (2003) report on several public opinion polls applied to health care. A survey fielded by the Roper Center for Public Opinion at the University of Connecticut in 1996, asked a representative sample of the public about their Afeelings@ towards for-profit health-care. Reactions were evenly split between positive and negative responses. More importantly, 24 percent of the public said that they were not familiar with the term. A second survey, conducted after a series of well-publicized scandals involving the Columbia/HCA investor-owned health care corporation asked respondents whether Athe Columbia/HCA hospital chaine was a for-profit or non-profit chain. Thirty-percent identified it (incorrectly) as nonprofit, 12 percent as for-profit, with the remainder acknowledging that they did not know the answer. [See

www.ropercenter.uconn.edu, Accession numbers 0279764 and 0355022, respectively.]

If so, do consumers expect nonprofit organizations to behave in a more trustworthy manner than their for-profit counterparts? Surveys of consumers in a variety of different industries, including insurance, health, and day care suggest that individual consumers hold more favorable impressions of nonprofit providers than of their for-profit counterparts. Among parents with children in day care, 25 percent felt that the quality of services differed by ownership, with most believing that quality in private nonprofit centers was higher than that found in their for-profit counterparts (Mauser, 1993). Surveys of individuals choosing among health care plans have found that about 56 percent indicate that they consider the ownership of the plan to be relevant for their selection (Towers Perrin, 1995). Of those who felt that ownership was relevant, the vast majority (46 percent of the total sample) preferred plans with nonprofit ownership. It is less clear that ownership-related expectations extend to markets in which there is substantial institutional purchasing. For example, utilization review services that assess the appropriateness of medical services are primarily purchased by employers and insurers. A recent survey of the UR industry found that only a small number of nonprofit managed care firms believed that ownership was important to their purchasers (Schlesinger et al 1996).

These inter-industry patterns are broadly consistent with the trustworthiness hypothesis. In markets in which services are purchased by organizations that can develop expertise in evaluating products, ownership is generally thought to have little informational value to purchasers. Ownership appears to be relatively more important where individual consumers must choose among service providers. In day care, for example, between 20 and 55 percent of respondents conclude that it is difficult to judge quality, depending on the aspect of quality about which they were asked (Mauser, 1993). In health care, 60 to 65 percent (depending on the wording of the question) lacked confidence in their understanding of differences among health care plans and in their ability to effectively choose the one most appropriate for their needs (Towers Perrin, 1995). Only 10 to 15 percent of those surveyed reported that they were willing to "trust a lot" information supplied to them by health insurance plans or managed care companies (Towers Perrin, 1995).

\section{Evaluating Existing Empirical Research}

There are two standards to which these studies can be held. The first is whether they convincingly answer the questions that their authors set out to address. The second is whether they answer the questions that one must answer to determine if asymmetric information can account for the role of nonprofit enterprise in mixed industries. Put somewhat differently, to what extent can evidence on the behavior of nonprofit organizations answer the questions raised in the previous section. 
Judging Past Research On Its Own Terms: Empirical research suggests that ownership is associated with some differences in consumer perceptions and organizational behavior. Whether this can be taken as reliable evidence supporting the trust hypothesis, however, is open to questions. This is equally true whether one is trying to determine if nonprofit organizations are more trusted or more trustworthy.

Central to claims about trust is the evidence that consumers consider nonprofit ownership a marker for some aspect of oganizational behavior. But we don't know exctly what consumers have in mind when they respond to these questions. None of the surveys on which these comparisons are based actually asked consumers about whether they in fact trust providers -only about the importance of ownership in choosing a provider of services. Nor do we know how these perceptions related to the consumers' knowledge or subsequent behavior in choosing a provider of services.

The relationship between ownership and trustworthiness is equally difficult to verify. Consumers may, for example, pay less for services in for-profit settings and get correspondingly lower quality. The complaints and dissatisfaction which result may have more to do with the actual level of delivered quality than deviations between expectations and realizations.

Alternatively, consumers may complain less because they trust nonprofits more, whether or not nonprofits are actually more trustworthy. Consumers who experience a given level of service may be unsure, even after the fact, whether it represented high or low quality. In more trusted settings, they may simply interpret their experiences in more positive ways, leading to fewer complaints and higher reported levels of satisfaction.

Judging Past Research On Our Terms: Although it provides some useful insights into ownership-related behavior, past empirical research falls short of allowing us to explain the existence of nonprofit ownership in terms of trust. In part, this is a problem of analytic methods. As we discussed earlier, the most plausible ways in which trust-related differences might persist in industries with mixed ownership involve equilibria in which there is a mix of trustworthy and untrustworthy behavior among for-profit and nonprofit organizations. But past empirical research measures difference between for-profit and non-profit behavior in terms of means (or, the multivariate equivalent, a dummy variable related to ownership) when what we really need are studies of the distribution of behaviors in the nonprofit and for-profit sectors.

Another fundamental problem with existing evidence is that it provides little support for the claim that we can explain the existence of nonprofit organizations in terms of trust. Based on the findings reported above, even if every consumer who felt that he or she was unable to judge quality patronized a nonprofit organization, there simply are too many nonprofit day care centers and hospitals to account for their existence solely by clients who feel ill-informed. Mauser's findings suggest that the sorting of consumers based on their self-assessed information is not that extreme, that a substantial number of clients who consider it difficult to assess quality make use of proprietary day care centers, even when nonprofit centers operate in their community.

To better understand how we can improve empirical research in this area, we return to the three challenges to the trust hypothesis.

1. Reputational Ubiquity challenge: As framed above, this challenge emphasizes that the trust hypothesis depends upon a particular structure of consumer information: sufficient awareness that there are aspects of quality that are difficult for the individual consumer to assess, an unwillingness to rely upon the reputation of individual providers as a signal of performance in those aspects of quality, and an ability to perceive and make use of ownership as 
an alternative signal. Past empirical research has focused almost entirely on the last of these conditions, virtually ignoring the first two. In several industries, research has provided some clues about consumers' assessment of their own information, but provided virtually no information about their perceived vulnerability to opportunistic behavior on the part of service providers. (In other words, we know what proportion of consumers feel informed, but not how problematic they consider that ignorance.) Nor do we know much about the extent to which consumers rely upon the reputation of service providers to assess quality or about how accurate these reputations are in practice. We do know, however, that the theoretical predictions of the literature on asymmetric information have been tested experimentally, and essentially been confirmed (Davis \& Holt, 1993).

2. Incentive Compatibility challenge: we have argued that there is nothing inherent in the nondistribution constraint that reduces the incentives for misrepresentation. Indeed, we have conjectured, that the specific ways in which nonprofits work, as well as the lack of enforcement of regulations, and the lack of market discipline, might well combine to increase the incentives for mispresentation. To the extent that the NDC is effectively enforced, it limits the direct monetary return from misrepresentation (although it is interesting to note that there have been persistent attempts to make the nondistribution constraint less binding in this respect. Indirect monetary returns from misrepresentation (gift exchange ${ }^{31}$ ), or non-monetary returns (large staff, fancy office) are likely candidates to further undermine the effectiveness of the NDC, although the very nature of these returns makes them particularly difficult to assess. What we know little about is the relationship between non-monetary returns and misrepresentations.

3. Adulteration challenge: As indicated above, past empirical research has provided few if any insights into the extent of misrepresentation among nonprofit providers. We suggested above that religious affiliation may provide a bulwark against adulteration, by limiting the ability of for-profits in disguise to enter an industry or by providing more external oversight over the behavior of the nonprofit service provider. The empirical evidence on this score is mixed. There were no statistically significant differences between religiously affiliated nonprofit nursing homes and nursing homes without religious affiliation in terms of their violations of state regulations or the number of consumer complaints (Weisbrod \& Schlesinger 1986). On the other hand,

31 The literature on gift exchange is voluminous. In economics, Akerlof (1984) presents four views on gift exchange and efficiency wage theory. In anthropology, Bourdieu's seminal book (1977) presents numerous examples. The idea is that of an "exchange" in which a person makes a "gift" in anticipation of a later reward. For example, a manager may pay a worker a higher wage anticipating (and expecting) to get more effort in return. Or, a nonprofit manager may give the spouse of board member an administrative job to entice him to be less critical of certain accounting or spending practices. Casual empiricism suggest that such gift exchange is widespread. Unfortunately, it is also difficult to document which may explain why this subject has not attracted attention in the literature. 
religiously affiliated nursing homes and mental institutions reported higher levels of consumer satisfaction (Weisbrod 1995), and parents who felt unable to assess quality were more likely to select a religiously affiliated nonprofit day care center than other nonprofit centers (Mauser 1993)

Though suggestive, the evidence is too limited to support the conclusion that religious affiliation serves as an effective safeguard against adulteration. One reason for our limited understanding of the potential for adulteration is that we understand little about what prompts consumers to complain or report that they are dissatisfied with services. It makes considerable difference whether the higher dissatisfaction is based on greater expectations or lower actual performance. If nonprofit firms prove themselves "trustworthy" by not promising as much as they might, or by not elevating consumer expectations, then this creates less incentive for adulteration, because the rewards of being a nonprofit firm are circumscribed by their failure to maximize revenues (Hirth 1995). If, on the other hand, nonprofit firms are promising more (at a higher price), but more likely to deliver on that promise, the incentive for adulteration is enhanced. Here again, we need to know more about the ways in which consumers assess quality and the relationship between quality claims and the prices paid for services.

Anecdotal evidence -- much of it journalistic -- suggests significant attempts at both internal and external adulteration (Emshwiller 1995; Pound, Cohen, \& Loeb 1995). To the extent that it is in line with mounting evidence about the systemic failure of control in nonprofits (BenNer 1994), it points at another blind spot in the empirical research on the nonprofit and voluntary sector.

\section{F. Discussion and Conclusion}

In this chapter we examined this trust hypothesis: the claim that asymmetric information in the markets for certain goods and services can explain the existence of nonprofit enterprise in those markets. Specifically, it has been argued that the non-distribution constraint imposed by nonprofit status can be an effective consumer protection device in severe situations of asymmetric information where consumers (and donors) can not accurately assess the quantity and quality of the offered goods or services. We have argued that this hypothesis, in order to be viable, has to meet three challenges -- "reputational ubiquity", "incentive compatibility", and "adulteration".

Reputational ubiquity requires that consumers take ownership as a reliable predictor of trustworthiness in those cases where they do not know whether individual firm can be trusted. Specifically, nonprofits need to be trustworthy and they need to be trusted in cases where forprofits aren't and won't. We point out that this requires, among other things, that for-profits can afford to ignore reputational concerns and that consumers know whether a firm is nonprofit or not. Incentive compatibility requires that the nondistribution constraint and related tenets such as the reasonable compensation constraint suffice to prevent opportunistic behavior of those that found, or work in, nonprofits. If the incentive compatibility constraint and related tenets do not prevent such behavior effectively and nonprofit enterprise has in addition to rely on altruistic or ideologic motivations of those that found, and work in, nonprofits, then such firms will have to fight off a neverending stream of entrepreneurs and workers that are less altruistic or ideologic and, hence, may adulterate the essential nature of the nonprofit enterprise.

Our discussion of the conceptual underpinnings of the trust hypothesis draws on the contemporary literature on industrial organization in recognizing the importance of both reputation and agency problems in organizational behavior. We conclude that the trust hypothesis stands 
on shaky ground as a general proposition. It can be sustained only under particular conditions that have been neither carefully described in theory nor subject to empirical assessment.

We have also discussed the empirical reality of the trust hypothesis and find it wanting: the evidence suggest that it survives none of the three challenges that we identified. We are somewhat guarded in our assessment because the available evidence is spotty, relies on inadequate measures, and is limited to a small number of industries. Part of the problem is that studies have not be designed to address the three challenges that we have identified. Another part of the problem is that our challenges are not easily assessed both conceptually and empirically.

Based on our review of the available evidence we suggest that the nonprofit form might not be needed in areas such as health and education for the purpose that it is given by Hansmann's proposition (it might well have a justification for other reasons!); in health and education reputation seems to impose discipline on firms in similar ways as it imposes discipline on computer makers and airlines. The situation is less clear in areas such as day care and nursing homes where, for a variety of reasons, information flows are arguably weaker, and where the nonprofit form might in fact have the intended effect under certain circumstances. Although this evidence suggests that there do appear to be some ownership-related differences in aspects of organizational performance connected with asymmetric information, there is little evidence that this relates to trust per se or provides a rationale for the existence of nonprofit ownership in the industries that we focused on.

Our review of some of the recent empirical literature suggest in any case that ownership related quality differences - especially of the hard-to-detect variety -- are rather spurious and often appear to be an artifact of the construction of data sets and their analysis. It is clear that a number of factors that are poorly controlled for such as hard-to-detect quality, specific industry conditions, information flows, will continue to complicate a more confident conclusion. New data sets now available also seem to suggest that the traditional tripartite categorization into forprofits, nonprofits, and government owned organizations is deficient and misses important aspects of the provision of these services and that, in addition to market forces, questions of the internal organization of organizations plays an important role.

In a recent article Hansmann (2001) proposed a reform agenda for the law of nonprofit organizations that interestingly comes to conclusions somewhat similar to the ones that are implicit in our analysis. Says he,

" ... many of today's numerous commercial nonprofits are anachronistic, in the sense that the nonprofit form is no longer well suited to the services they produce. If these organizations were to be formed anew, they would probably be formed as for-profit entities instead." (p. 4)

We believe that this view reflects a convergence of Hansmann's and our views on the issue of the raison d'etre of the trust hypothesis as the primary safeguard in markets where information asymmetries between providers and consumers persist (such as the four human services segment that were the focus of our review of the empirical underpinnings of the trust hypothesis.)

We believe that the real issue today is whether nonprofit enterprise gives back to society (and how it gives back to society) what it receives in form of numerous tax and regulatory breaks and other donations. Greater trustworthiness represents one form of social contribution, albeit 
one which appears to be limited in significance to particular services. The question then becomes how to value this aspect of behavior in a manner commensurate with the other ways in which nonprofit activity may have social value. This is arguably as tough a problem as an assessment of the trust hypothesis because here too we face the important hurdle of how to measure reliably the achievements of nonprofits. 


\section{References}

Abrahamson, E and C Park (1994). Concealment of Negative Organizational Outcomes: An Agency Theory Perspective. Academy of Management Journal 37.5., 1141 - 66.

Akerlof, G (1970). The Market for Lemons: Quality Uncertainty and the Market Mechanism. The Quarterly Journal of Economics 84.3., 488 - 500.

(1984). Gift Exchange and Efficiency-Wage Theory: Four Views. American Economic Review 74.2., 79 - 83.

Anheier, H (1995). Theories of the Nonprofit Sector: Three Issues. Nonprofit and Voluntary Sector Quarterly 24.1., 15 - 24.

Aron, DJ (1990). Firm Organization and the Economic Approach to Personnel Management. American Economic Review 80.2., 23 - 27.

Arrow, K (1963). Uncertainty and the Welfare Economics of Medical Care. American Economic Review 54.4., 941 - 73.

Ballou, JP and BA Weisbrod (2002). Managerial rewards and the behavior of for-profit, governmental, and nonprofit organizations: evidence from the hospital industry. Journal of Public Economics (forthcoming)

Ben-Ner, A (1986). Nonprofit Organizations: Why Do They Exist in Market Economies? In S. Ross-Ackerman (1986), 94 - 113.

(1994). Who Benefits from the Nonprofit Sector? Reforming Law and Public Policy Towards Nonprofit Organizations. Yale Law Journal 104.3., 731 - 62.

(May 3, 1996), Message posted to cyb-acc discussion list.

and B Gui (eds) (1993). The Nonprofit Sector in the Mixed Economy. Ann Arbor: University of Michigan Press.

and T Van Hoomissen (1993). Nonprofit Organizations in the Mixed Economy: A Demand and Supply analysis. In Ben-Ner, A. \& B. Gui (1993), 27-58.

Bennett, JT and TJ DiLorenzo (1994). Unhealthy Charities. Hazardous to Your Health and Wealth. New York: Basic Books.

Bilodeau, M (1998). Rational Nonprofit Entrepreneurship. Journal of Economics \& Management Strategy 7.4., 551 - 572.

Bilodeau, M and A Slivinski (1996). Volunteering nonprofit entrepreneurial services. Journal of Economic Behavior \& Organization 31.2., 117 - 127.

Borjas, GH, Frech HE and P.B. Ginsburg (1983). Property Rights and Wages: The Case of Nursing Homes. Journal of Human Resources 18.2., 231 - 46. 
Bourdieu, P (1977). Outline of a Theory of Practice. Cambridge: Cambridge University Press.

Bradley, EH and LC Walker (1998). Education and Advance Care Planning in Nursing Homes:

The Impact of Ownership Type. Nonprofit and Voluntary Sector Quarterly 27.3., 339 - 57.

Brody, E (1996). Agents Without Principals: The Economic Convergence of the Nonprofit and For-Profit Organizational Forms. New York Law School Law Review 40.3., 457 - 536.

Carr, R (2000). Nonprofit Fraud Hard To Stop, Regulators Say. Cox Washington Bureau 10-1800 .

Chillemmi, O and B Gui (1991). Uninformed Customers and Nonprofit Organizations: Modelling 'Contract Failure' Theory. Economics Letters 25.1., 5 - 8.

Chipty, T (1995). Economic Effects of Quality Regulations in the Day-Care Industry. American Economic Review 85.2., 419 - 24.

Cryan, MA and P Gardner (1999). Balancing Mission and Market: Nonprofits Walk a Tightrope Between the Public and Private Spheres. Consumers Union report.

Davis, DD and CA Holt (1993). Experimental Economics. Princeton University Press.

DiMaggio, P and H Anheier (1990). The Sociology of Nonprofit Organizations and Sectors. Annual Review of Sociology 16, 137 - 59.

DiMaggio, P and WW Powell (1983). The Iron Cage Revisited: Institutional Isomorphism and Collective Rationality in Organizational Fields. American Sociological Review 48, 147 60.

Douglas, S and K Mills (2000). Nonprofit fraund: What are the key indicators? Canadian FundRaiser August 16.

Duggan, MG (2000). Hospital Ownership and Public Medical Spending. Quarterly Journal of Economics 114.5., $1343-73$.

Easley, D and M O'Hara (1983). The Economic Role of Nonprofit Firms. Bell Journal of Economics 14.3., 531 - 38.

------ (1986). Optimal Nonprofit Firms. In S. Ross-Ackerman (1986), 85 - 93.

Emshwiller, JR (1995). More Small Firms Complain About Tax-Exempt Rivals. Wall Street Journal, August 8.

Etzioni A and P Doty (1976). Profit in Not-for-Profit Corporations: The Example of Health Care. Political Science Quarterly 91.3., 431 - 53.

Facchina, B, EA Showell and JE Stone (1993). Privileges and Exemptions Enjoyed by Nonprofit Organizations. University of San Francisco Law Review 28 (Fall), 85 - 121.

Galaskiewicz, J and W Bielefeld (1998), Nonprofit Organizations in Age of Uncertainty. New 
York: Aldine De Gruyter.

Gaul, GM and NA Borowski (1993). Free Ride: The Tax Free Economy. Kansas City: Andrews and McMeel.

Gelles, E (1999). For-Profit versus Non-Profit: Does Economic Sector Make a Difference in ChildCare. Journal of Health and Human Services Administration 22.2., 156 - 73.

Glaser, J (1994), The United Way Scandal, an insider's account of what went wrong and why. New York: John Wiley \& Sons.

Glaeser, EL and A Shleifer (2001). Not-for-profit entrepreneurs. Journal of Public Economics 81, $99-115$.

Glazer, A and KA Konrad (1996). A Signaling Explanation for Charity. The American Economic Review 86, 1019 - 1028.

Goeree, J and CA Holt (1999). Stochastic Game Theory: For Playing Games, Not Just for Doing Theory. Proceedings of the National Academy of Sciences 96 (September), 10,564 - 67.

------ (2001). Ten Little Treasures of Game Theory and Ten Intuitive Contradictions. American Economic Review 91.5., 1402 - 1422.

Goldberg, V (1975). Some Emerging Problems in Prepaid Health Plans in the Medi-Cal System. Policy Analysis 1.4., 55-68.

Gray, B (1991). The Profit Motive and Patient Care: The Changing Accountability of Doctors and Hospitals. Cambridge, MA: Harvard University Press.

Hall, PD, E Brody and A Ortmann (1999). Review (of Hansmann's Ownership of Enterprise.) Nonprofit and Voluntary Sector Quarterly 28.2., 213 - 234.

Hammack, DC (2001). Introduction: Growth, Transformation, and Quiet Revolution in the Nonprofit Sector Over Two Centuries. Nonprofit and Voluntary Sector Quarterly 30.2., 157 $-173$.

Handy, F (1996). Reputation as Collateral: An Economic Analysis of the Role of Trustees of Nonprofits. Nonprofit and Voluntary Sector Quarterly 24.4., 293-305.

Hansmann, H (1980). The Role of Nonprofit Enterprise. Yale Law Journal 89.3., 835-901. [PONPO working paper no.1]

(1987). Economic Theories of Nonprofit Organizations. In Powell, W.W. (1987)

(1994). Organization of Production in the Human Services. [PONPO working paper no. 200]

(1996). The Ownership of Enterprise. Cambridge, MA:

Harvard University Press. 
------ (2000). Response to Hall, Brody, Ortmann (1999).

Nonprofit and Voluntary Sector Quarterly, 29.1., 179-184.

(2001). A Reform Agenda for the Law of Nonprofit Organizations.

pp. 241 - 72 in: Hopt, K and D Reuter (eds). Stiftungsrecht in Europa. Koeln: Carl

Heymanns Verlag [here cited after the March 2000 manuscript]

Harbaugh, WT (1998). What Do Donations Buy? A Model of

Philanthropy Based on Prestige and Warm-Glow. Journal of Public Economics 67, 269 84.

------ (1998a). The Prestige Motive for Making Charitable Transfers.

American Economic Review 88, 277 - 82.

Hart, O (1995). Corporate Governance: Some Theory and Implications. Economic Journal 105, 678-689.

------ (2001). Financial Contracting. Journal of Economic Literature 39.4., 1079 - 1100.

Heal, G (1976). Do Bad Products Drive Out Good? Quarterly Journal of Economics 95.3., 499 502.

Helburn, SW (ed.) (1995). Cost, Quality, and Child Outcomes in Child Care Centers: Technical Report. Denver: Department of Economics, Center for Research in Economic and Social Policy, University of Colorado at Denver.

Hertwig, R and A Ortmann (2001). Experimental practices in economics:

A methodological challenge for psychologists. Behavioral and Brain Sciences 24.3., $383-$ 403.

Herzlinger, R (1996). Can Trust in Government and Nonprofits Be Restored? Harvard Business Review 74, 97 - 106.

Hirth, RA (1995). Consumer information and ownership in the nursing home industry. Working paper.

Hirth, R.A. (1999). Consumer Information and competition between nonprofit and for-profit nursing homes. Journal of Health Economics 18, 219 - 240.

Holmstroem, B and J Tirole (1989). The Theory of the Firm. In: R Schmalensee and RD Wittig (eds). Handbook of Industrial Organization. New York: Elsevier, 61-133.

James, E (1986). In S Rose-Ackerman (1986), 154-58.

Jeavons, TH (1994). Ethics in Nonprofit Management: Creating Culture of Integrity. In: Herman, $\mathrm{R}$ and Associates (1994), 184 - 207.

Kessler, D and M McClellan (2001), The Effects of Hospital Ownership on Medical Productivity. NBER Working Paper No. 8537. 
Kingma, B (1997). Public good theories of the non-profit sector revisited: Weisbrod revisited. Voluntas 8.2., $134-148$.

Klein, B and K Leffler (1981). The Role of Market Forces in Assuring Contractual Compliance. Journal of Political Economy 91.3., 615-40.

Kreps, DM (1990). Corporate Culture and Economic Theory. In: Alt, J and K Shepsle (eds). Perspectives on Positive Political Economy. Cambridge: Cambridge University press, 90 143.

Labaton, S (2002). Audit Group's Chief to Donate Disputed Stock to a Charity. New York Times March 30.

Ledyard, JO (1995). Public Goods: A Survey of Experimental Research. In: AE Roth and JH Kagel (eds). The Handbook of Experimental Research. Princeton: Princeton University Press.

Leete, $L$ (2001). Wither the Nonprofit Wage Differential? Estimates from the 1990 Census. Journal of Labor Economics 19.1., 136 - 170.

Lewis, LS (2000). When Power Corrupts: Academic Governing Boards in the Shadow of the Adelphi Case. New Brunswick: Transactions Pub.

Luksetich, W, M Edwards and T Carroll (2000). Organizational Form and Nursing Home Behavior. Nonprofit and Voluntary Sector Quarterly 29.2., 255 - 256.

Mark, T (1996). Psychiatric Hospital Ownership and Performance. Do Nonprofit Organizations Offer Advantages in Markets Characterized by Asymmetric Information? Working paper.

Marmor, T, M Schlesinger and R Smithey (1986). A New Look at Nonprofits: Health Care Policy in the Competitive Age. Yale Journal of Regulation 3.2., 313 - 50.

Massy, WF and R Zemsky (1994). Faculty Discretionary Time. Departments and the 'Academic Ratchet.' Journal of Higher Education 65.1., 1- 22.

Mauser, E (1993). The Importance of Organizational Form: Parent Perceptions Versus Reality in the Day-Care Industry. Working paper.

Milgrom, P and JRoberts (1990). The Efficiency of Organizational Decision Processes. American Economic Review 80.3., 511 - 28.

Mocan, HN (1995). Quality-Adjusted Cost Functions for Child-Care Centers. American Economic Review 85.2., 409 - 13.

------ (1997). Cost Functions, Efficiency, and Quality in Day Care Centers. Journal of Human Resources 32.4., $861-91$.

Morris, JK and SW Helburn (2000). Child Care Center Quality Differences: The Role of Profit Status, Client Preferences, and Trust. Nonprofit 
and Voluntary Sector Quarterly 29, 377 - 99.

(1997). Cost and quality in child care centers: Data set documentation manual. Champaign: ERIC Clearing House.

Moulton, G and K Wilson (2000). Nonprofit fraud: Focus on segregation of duties and good reporting procedures. Canadian FundRaiser September 20.

Needleman, J (1998). Nonprofit to For-Profit Conversions by Hospitals and Health Plans: A Review. White paper [www.pioneerinstitute.org]

Nelson, RR and M Krashinsky (1973). Two Major Issues of Public Policy: Public Policy and the Organization Supply. In R. Nelson and D. Young (eds). Public Subsidy for Day Care Centers in the United states. Lexington, MA: D.C. Heath.

Newhouse, J (1970). Toward a Theory of Non-profit Institutions: An Economic Model of a Hospital. American Economic Review 60.2., 64-73.

Nicklin, JL (2000). Colleges Are Evasive About Presidents' Benefits Packages. Chronicle of Higher Education November 24.

Odenthal, TJ (1990). Charity Begins at Home. Generosity and Self-Interest Among the Philanthropic Elite. New York: Basic Books.

Ortmann, A (1996). Modern Economic Theory and The Study of Nonprofit Organizations: Why the Twain Shall Meet. Nonprofit and Voluntary Sector Quarterly, 25.4., 47- 84.

------ (1997). How to survive in post-industrial environments: Adam Smith's advice for today's colleges and universities. Journal of Higher Education 68.4., 483 - 501.

(1998). The emergence of a for-profit higher education sector:

recent developments . Presentation at the ARNOVA Conference, Seattle, WA, 1998.

(2001) Capital Romance: Why Wall Street Fell in Love With

Higher Education. Education Economics 9.3., 293 - 311.

and D Colander (1997). A Simple Principal-Agent Game for the Classroom. Economic Inquiry.

and R Squire (2000). The Organization of the Liberal Arts College: A Game-Theoretic Analysis. Journal of Economic Behavior and Organization 43.3., 377 - 392.

Oster, S (1986). In S. Rose-Ackerman (1986), 152-54.

------ (1995). Strategic Management of Nonprofit Organizations. Oxford: Oxford University Press.

Powell, W (ed) (1987). The Nonprofit Sector: A Research Handbook. New Haven: Yale University Press.

Preston, A (1988). The Effects of Property Rights on Labor Costs of Nonprofit Firms: An Application to the Day Care Industry. Journal of Industrial Economics 36.3., 337 - 50. 
(1989). The Nonprofit Worker in a For-Profit World. Journal of Labor Economics 7.4., 438 63.

Pound, ET., G Cohen and P Loeb (1995). Tax Exempt! Many Nonprofits Look and Act Like Normal Companies-Running Businesses, Making Money. So Why Aren't They paying Uncle Sam? U.S. News and World Report, October 2, 36-51.

Roomkin, MJ and BA Weisbrod (1999). Managerial Compensation and Incentives in For-Profit and Nonprofit Hospitals. Journal of Law, Economics, and Organization. 15.3., 750 - 781.

Rose-Ackerman, S (ed) (1986). The Economics of Nonprofit Institutions: Studies in Structure and Policy. New York: Oxford University Press.

(1996). Altruism, Nonprofits, and Economic Theory. Journal of Economic Literature 34.2., 701-28.

------ (1997). Altruism, ideological entrepreneurs and the non-profit firm. Voluntas 8.2., $120-134$.

Schlesinger, M, B Gray, and E Bradley (1996). Charity and Community: The role of nonprofit ownership in a managed health care system. Journal of Health Politics Policy and Law 21.4., ...

Schlesinger M and B Gray (2003). Nonprofit Organizations and Health Care: Burgeoning Research, Shifting Expectations, and Persisting Puzzles. In: R Steinberg and W Powell The Nonprofit Sector: A Research Handbook, Second Edition Ed. New Haven: Yale University Press.

Silk, T (1994). The Legal Framework of the Nonprofit Sector in the United States. In Herman, R. and Associates (1994), 65 - 82.

Sloan, FA, GA Picone, DH Taylor Jr. and S Chou (2001). Hospital ownership and cost and quality of care: is there a dime's worth of difference? Journal of Health Economics 20.1., 1 - 21.

Sontag, D (2001). Self-Inflicted Wounds. How the Red Cross came apart. The New York Times Magazine 23. December .

Sparrow, MK (2000). License to Steal: How Fraud and Abuse Bleeds America's Health Care System. $2^{\text {nd }}$ Edition. Boulder: Westview Press.

Steinberg, R (1993). Public Policy and the Performance of Nonprofit Organizations: A General Framework. Nonprofit and Voluntary Sector Quarterly 22.1., 13 - 31.

and BH Gray (1993). The Role of Nonprofit Enterprise. Nonprofit and Voluntary Sector Quarterly 23.4., 297 - 316.

Stiglitz, J (1989). Imperfect Information in the Product Market. In: R. Schmalensee and R.D. Wittig (eds): Handbook of Industrial Organization. New York: Elsevier 769 - 847. 
Thayer, F (2002). The Public-Private Partnership Follies: In Four Acts. Act Illa: ASPA, NAPA, NASPAA and "Cooperation vd. Competition" ASPA Online Column 3/08/02.

Tirole, J (1988). The Theory of Industrial Organization. Cambridge: MIT Press.

Towers Perrin (1995). Navigating the Changing Healthcare System: The Tower Perrin Survey of What Americans Know and Need to Know. New York: Louis Harris.

Weisbrod, B (1975). Toward a Theory of the Voluntary Nonprofit Sector in a Three-Sector Economy. In: E. Phelps (ed) Altruism, Morality and Economic Theory. New York: Russell Sage Foundation.

- (1988). The Nonprofit Economy. Cambridge, MA: Harvard University Press.

(1983). Nonprofit and Proprietary Sector Behavior:

Wage Differentials among Lawyers. Journal of Labor Economics 1, 246 - 63.

------ and M Schlesinger (1986). Ownership form and behavior in regulated markets with asymmetric information. In: Rose-Ackerman (1986), 133 - 51.

------ and B Erus (2001). Compensation Structures

Across Institutional Forms: Responses to Exogenous Revenue Constraints in the Hospital Industry, 1992 - 1997. Manuscript.

Williamson, OE (1970). Managerial Discretion and Business Behavior. American Economic Review 60.5.,1032 - 1056.

Young, D (1983). If not for profit, for what? Lexington, MA: Heath.

------ (1986). Entrepreneurship and the Behavior of Nonprofit Organizations: Elements of a Theory. In Rose-Ackerman (1986), 161-84.

Young, DR and R Steinberg (1995). Economics for Nonprofit Managers. New York: The Foundation Center.

Zall, B (Jan 23, 2002), Message posted to cyb-acc discussion list. 